\title{
Leigh Hunt and the Dashwood Annuity
}

\author{
D A V I D R. CHENEY
}

Leigh Hunt was desperate for money throughout his life but was tantalized from time to time with the prospect of becoming rich or at least comfortable. ${ }^{1}$ For example, there was the large inheritance expected from his wealthy American maternal grandfather, Stephen Shewell, only $£ 330$ of which ever materialized. ${ }^{2}$ There was the generous $£ 2,000$ legacy from Shelley which by the time he received it in 1844 had shrunk to an annuity of $£ 120$ per year. ${ }^{3}$ There was the government pension that Hunt eagerly expected for several years before $£ 200$ per year finally was settled upon him in $1847 .{ }^{4}$ Also, every time Hunt started a new journal, he expected it to make his fortune, whether it was the Reflector, Indicator, Liberal, Companion, Leigh Hunt's London Journal, or even the Plain Dealer that lasted for just three weeks. In spite of all the disappointments, however, he remained optimistic and was always enthusiastic about any adventure that offered money. Consequently, when in 1835 , during one of his most difficult financial periods, the wealthy Mrs. Anna Maria Dashwood invited Hunt to visit her in Wales to discuss setting up an annuity for him, he eagerly accepted. ${ }^{5}$

The resulting two-week trip in August and September of 1835 is a fascinating but little known episode in Hunt's life. Hunt, himself, does not mention it in his Autobiography nor does Ann Blainey in the most

\footnotetext{
${ }^{1}$ Acknowledgment for providing me with copies of the letters here quoted from and for permission to publish them is made to The University of Iowa Libraries. I am grateful to the University of Toledo for research grants, summer fellowships, and sabbaticals, which have provided the funds to procure copies of the letters and time to transcribe and annotate them. I wish particularly to acknowledge the generous and unstinting help over the past several years of Frank Paluka, former head of Special Collections at The University of lowa, in connection with my project of editing the letters of Leigh Hunt.

2 Letter to John Hunt dated July 14, 1812 (Pierpont Morgan Library, M.A. 987 [V|8|C] F.) and Stephen F. Fogle, "Leigh Hunt's Lost Brother and the American Legacy," Keats-Shelley Journal 8 (1959): 98-101.

${ }^{3}$ Louis Landré, Leigh Hunt: Contribution a l'histoire du Romantisme anglais (Paris: Société d'Édition “Les Belles Lettres," 1936), 1: 243.

4 "Hunt, James Henry Leigh," DNB, 272.

${ }^{5}$ Edmund Blunden, Leigh Hunt: A Biography (London: Cobden-Sanderson, 1930): 258, 264.
} 


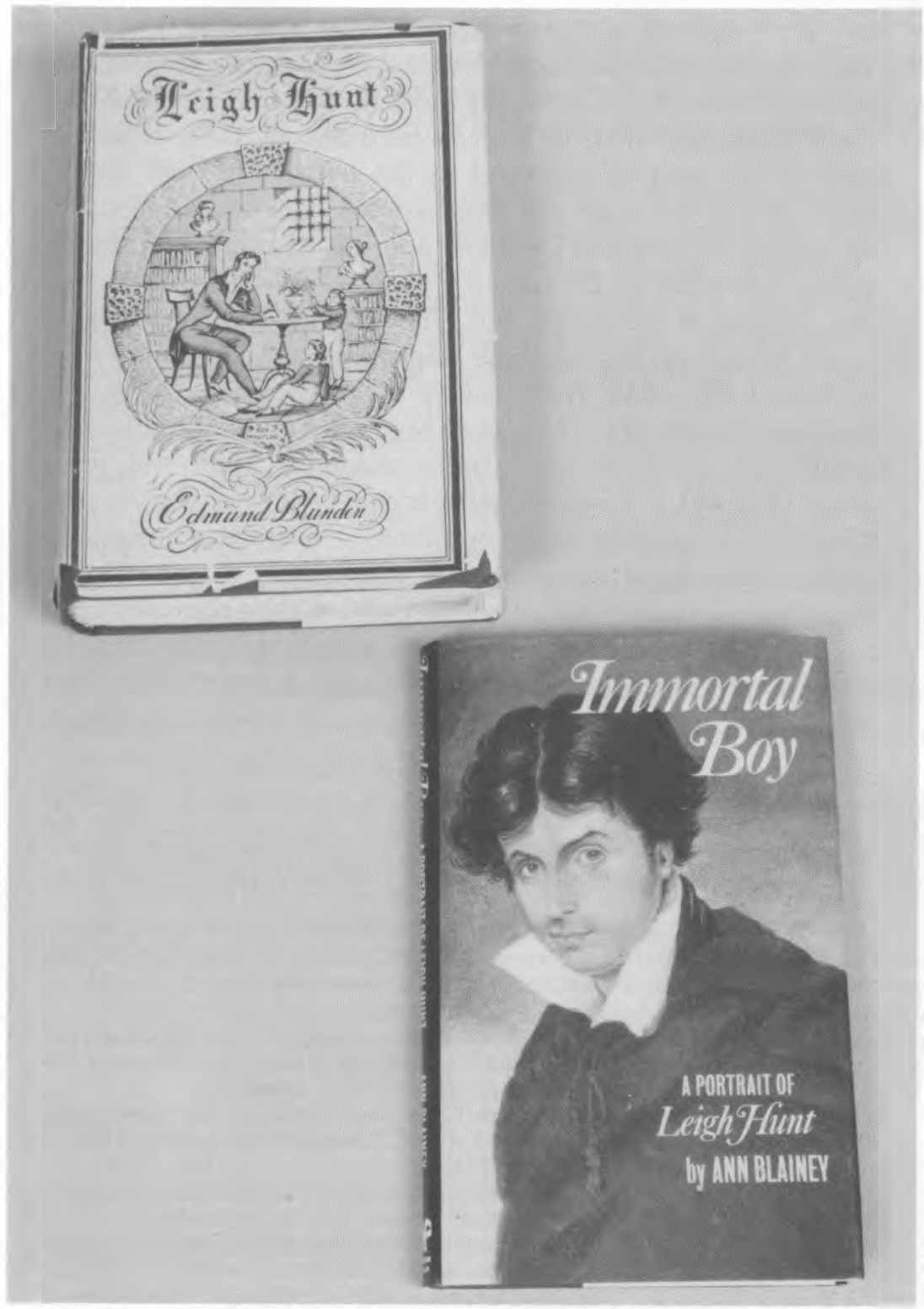

Two biographies of Leigh Hunt with their dust jackets. 
recent biography of Hunt. ${ }^{6}$ Edmund Blunden (p. 264) devotes but a short paragraph to it and Louis Landre $(1: 202-3)$ only two sentences. Yet it is an important episode inasmuch as it involved a project that Hunt no doubt thought would finally make him financially secure, and it is typical in that the project was not as successful as anticipated. Also, the descriptions of some of the places he visited are as delightfully detailed in letters to his wife, Marianne, as are those of Oxford, Lincoln, Nottingham, and Cambridge where he went for his health earlier in the century. ${ }^{7}$

Much of the story is contained in the ten letters Hunt wrote to Marianne during the trip, ${ }^{8}$ but there are also brief comments in two letters written to Dalby and DeWilde ${ }^{9}$ after the trip was over, and there are public references to the trip in a series of essays in Leigh Hunt's London Journal in November and December of 1835,10 and in two poems on Bodryddan and Llanbedr respectively. ${ }^{11}$ There is also a letter dated August 22, 1835, from Hunt's wife, Marianne, to Hunt and another dated August 19, 1835, from Mrs. Dashwood to Marianne.

Actually the adventure began quite modestly. Hunt and Egerton Webbe (?1810-40), a young musician friend ${ }^{12}$ who was writing articles for Leigh Hunt's London Journal at the time, ${ }^{13}$ were planning a holiday to Stratford-upon-Avon to see the sights, take walks, and enjoy a leisurely vacation for their health's sake. ${ }^{14}$ Apparently, as their plans were taking shape, the invitation arrived from Mrs. Dashwood and another Hunt admirer, Joseph Ablett, friend of Walter Savage Landor (1775-1864)15

- Immortal Boy: A Portrait of Leigh Hunt (London: Croom Helm, 1985).

7 See, among others, letters to Marianne dated April 22, 1803 (MS, Brewer Collection, The University of lowa Libraries, MsL|H94hum|No. 1); February 27, 1806 (MS, British Library, Ashley 3393, ff. 1-4); June 13, 1808 (MS, British Library, Ashley 3393, ff. 7-8); and January 4, 1811 (MS, Brewer Collection, The University of Iowa Libraries, MsL|H94hum4|No. 9).

${ }^{8}$ Letters from Oxford on August 21, 1835; from Stratford-upon-Avon on August 22; from Stafford on August 24; from Chester on August 24; from Rhyll on August 25, 26, 30, and September 1 and 2; and from Llanbedr Hall on September 3.

${ }^{9}$ On October 19 and November 2, 1835, respectively.

10 Under the title "A Journey by Coach," the essays appeared November 14, 21, and 28 and December 12. The series ceased with the termination of Leigh Hunt's London Journal at the end of 1835 and before Hunt had gotten well out of London.

"1 "Bodryddan, the Residence of Barbara Y. and Anna Maria D." first published in the Monthly Repository 1 (October 1837): 243-46 and "Llanbedr" first published in Literary Hours (Liverpool: George Smith, 1837): 211-12.

12 He wrote some of the music for Hunt's play Legend of Florence, which was produced in 1840 at Covent Garden.

${ }^{13}$ Number seven of a series by Webbe entitled "Thoughts on Language" was printed in Leigh Hunt's London Journal 2 (August 22, 1835): 274-75.

14 "A Journey by Coach," Leigh Hunt's London loumal 2 (November 14, 1835): 393.

15 Author and poet. He had just published several poems in Leigh Hunt's London Journal. 
and editor of Literary Hours. ${ }^{16}$ Hunt, of course, was eager to go so the already-planned trip was adjusted. Hunt and Webbe would, indeed, go to Stratford, but, instead of spending several leisurely days there and then returning to London, they would pause only briefly before continuing through Stafford to Birmingham, for an overnight stay, and finally to Chester where they would part company. Webbe would visit friends in the area, while Hunt went on to Bodryddan in Wales to visit with Mrs. Dashwood for a week, then stop for a day with Ablett at Llanbedr before returning to London.

Hunt and Webbe had originally planned to leave London on August 19 , but one of them, probably Webbe, was too sick to go on that day, and indeed, when they finally started on August 21, had to get out of a sickbed against doctor's orders leaving the nurse "in a state of 'inconceivability." "17 After a first day's exhausting journey, they spent the night in a double-bedded room in a "great inn" in Oxford near Shelley's University College. ${ }^{18}$

According to his letter written to Marianne on August 21 from Oxford, Hunt was still on the planned schedule "to be in Stratford tomorrow noon, to sleep at Birmingham at night, \& be in Chester the night following." 19 Instead of spending the night in Birmingham, however, they spent it in Stratford-upon-Avon in "a very little inn ... opposite" Shakespeare's birthplace where they "inscribed" their names "among a heap with which the walls and ceiling are covered."'20

No doubt Hunt was grateful that they did not spend the night in Birmingham as they had originally planned because he found it to be one of the most depressing places he had ever been.

Oh, Birmingham is such a horrible place!-literally, for fourteen miles one way, \& twenty miles another, a region of furnaces, machinery, \& fields full of cinders! The road was through them, and the horizon is as full of chimnies as a city of steeples, some of them eternally spouting fire. Then the sick faces \& pale children-oh you cannot conceive what a detestable district it is. We were as glad to get out of it, as if it had been the infernal regions. It far surpassed even my imagination of it, \& you may guess what it must be to do that. Almost every field contains iron or coal machinery of some sort, with hovels round it for the wretched workmen, \& the whole district is literally blighted \& burnt up. Imagine the worst cinder-corner

16 Landre, 2: 499.

17 "A Journey by Coach," p. 393 and letter to Marianne Hunt dated August 25, 1835 (MS, Brewer Collection, The University of lowa Libraries, MsL/H94hum11|No. 2).

18 "A Journey by Coach," p. 393 and letter to Marianne Hunt dated August 22, 1835 (Published in Thornton Hunt [ed.], Correspondence of Leigh Hunt. 2 vols. [London: Smith, Elder and Company, 1862]), 1: 276-77.

19 MS, Brewer Collection, The University of Iowa Libraries, MsL|H94hum 10.

${ }^{20}$ Letter to Marianne Hunt dated August 22, 1835. 
you ever saw in the worst bit of suburb pretending to be a field, \& the whole region is literally made up of it. ${ }^{21}$

Hunt and Webbe had hoped to get to Chester by August 23, but were delayed a day since they not only spent extra time in Stratford-uponAvon, but, as Hunt wrote in his letter from Stafford dated August 24

We were disappointed yesterday in getting a Liverpool coach to Chester; it could only bring us as far as this place; so we missed the Chester mail, having reckoned confidently on one of the numerous Liverpool coaches, none of which turned out to go through that city. ... So we were obliged to stop here a whole Sunday, \& a melancholy Sunday it was, \& Stafford is a melancholy place, such as you expect from a city of shoemakers.

While the first day's journey had made Hunt and Webbe sicker, on the second day Hunt wrote that Webbe was mending, ${ }^{22}$ and on the fourth day, August 24, Hunt commented that "Mr. Webbe \& I laugh \& talk of Shakspeare, \& get on like a couple of proper philosophic invalids." 23

They arrived in Chester on the morning of August 24, and apparently Hunt spent some of the day thereafter parting from Webbe for he described in a letter to Marianne the unusual double sidewalks in the city, one a floor above the other, and noted that he planned to see the old city walls. ${ }^{24}$ This letter and another to his eldest son, Thornton, seem to have been written in a Chester hotel because in the letter to Thornton, he wrote that "a Welsh girl is at this moment playing the native harp in the hotel here, while I am writing." 25 Hunt probably had dinner in the hotel for he did not spend the night there. A postscript to his letter to Marianne of the twenty-fourth indicates that he was going to St. Asaph that night and would get to Rhyll the next morning. 26

Hunt did arrive at St. Asaph the evening of August 24 but did not stay the night as he had intended. A note from Mrs. Dashwood dated August 21 was waiting for him requesting that he drop her a line, which would reach her next morning. However, after writing the line, Hunt discovered that floods prevented a messenger from getting through. Consequently, that night he continued on "to Rhyll \& put up at the Mostyn Arms" as Mrs. Dashwood had advised and where he was pleased that he knew Mrs. Dashwood because "I think I can discern that there is a double portion

${ }^{21}$ Letter to Marianne Hunt dated from Stafford August 24, 1835 (MS, Brewer Collection, The University of Iowa Libraries, MsL|H94hum11|No. 1).

22 Letter to Marianne Hunt dated August 22, 1835.

${ }^{23}$ Letter to Marianne Hunt dated from Stafford August 24, 1835.

${ }^{24}$ Letter to Marianne Hunt dated from Chester August 24, 1835 (MS, Carl H. Pforzheimer Library, LH 193).

25 Letter to Thornton Hunt dated August 24, 1835 (MS, Brewer Collection, The University of lowa Libraries, MsL|H94hut|No. 4).

${ }^{26}$ Letter to Marianne Hunt dated from Chester August 24, 1835. 
of attention shewn me on account of my great acquaintance in the neighbourhood." 27

From Rhyll on the morning of the twenty-fifth, Hunt wrote a second note to which he shortly received a "kind" answer from Mrs. Dashwood, and, as he reported to Marianne, "I am to drink tea with her \& her aunt this evening at 7." 28 While waiting for the appointment, Hunt had leisure to explore Rhyll and describe it and the Welsh people in some detail to Marianne.

The country is flat indeed just here, but then it is sea-shore (though I have not yet seen the sea except at a distance, the day has been so rainy). And the neighbourhood of St. Asaph is beautiful; \& I see mountains where I am. I passed the site of Bodryddan, coming hither, - \& saw Rudlen [sic] Castle, which is a most magnificent ruin, with huge round towers, and a wall draperied with ivy. It is strange to hear the people talking Welsh, but they speak English also (the middle sort) much more than I expected. This however is but the border of Wales. They are a handsome people, as far as I have seen, - decidedly so, - with faces intelligent \& goodhumoured; \& the girls' looks have a certain refinement rarely seen in English peasantry. I do not know how to account for this; so I must try \& find it out. The waiter at St. Asaph was one of the most Welsh Welshmen I ever beheld, as if Wales was resolved to give me a thorough specimen at once; only I treated him well, so I got no Welsh anger. He was a short stout man, with a broad but good face, light tones like Sir Hugh Evans, \& a never-failing complaisance. Every "Yes" was "Yes, surely Sir." 29

Apparently Mrs. Dashwood had already sent some money to Hunt for, in anticipating seeing her, Hunt wrote to Marianne, "You may think I shall behold with affection the face of one, who has done so much for me $\&$ mine. If I did not, they would have less reason to love me, \& I assuredly could not have loved them so much as I do; for is not the affection, gratitude for their \& your dear sakes?"' But Hunt seems to have decided that his enthusiasm for Mrs. Dashwood might arouse jealousy in Marianne for he added, "But oh! do not for an instant suppose-But you don't suppose: so I will not do you the injustice of making unnecessary protestations." 30 In other letters, too, Hunt seems to have felt that his comments about Mrs. Dashwood might make Marianne jealous for he seems to have felt constantly compelled to reassure her. For example, in another letter, he wrote about Mrs. Dashwood kissing the tears in his eyes, and then he abruptly shifted to say he thought Marianne would love

${ }^{27}$ Letter to Marianne Hunt dated August 25, 1835.

28 Ibid.

29 Ibid.

30 Ibid. 
her if she were with her. ${ }^{31}$ In his last letter of the trip, he wrote, "it was a melancholy moment, the taking leave of our dear friend, who overflows, like yourself, with generous feelings. I shall never cease to think most affectionately of her, nor would you wish me."'32

Hunt had reason for misgivings because Mrs. Dashwood, perhaps another of Hunt's several "emotional conquests," as Ann Blainey phrases it (p. 161), had recently written rather warmly about him to Marianne.

Long have I loved your husband-his high \& kindly feelings have been long my delight:-for they belong - they are part, as it were, of a world beautiful as ours is - they stand apart from the unkindness, the cruelty of it-which ought not, in fact, to make part of it ... may your husband so teach, so enclose [my mind] with his own lofty feelings, that he may leave me a happier, or better being — \& may I—God grant I may—never prove unworthy of his tender love \& yours - \& if I may contribute to your happiness in any way, believe me my dear Mrs. Hunt, my heart will be a blessed one-for it will ever be yours \& your Husbands. ${ }^{33}$

Whether or not Hunt felt that he was walking a tightrope, after he had actually seen Mrs. Dashwood, he gave Marianne only a brief and circumspect description of the evening tea.

I have the pleasure of telling you that I spent a very quiet, agreeable evening yesterday, according to the appointment to tea which I spoke of in my last. I saw her first, \& had a most hearty, goodnatured reception, such as you would have liked to see; and then she took me from the parlour, \& introduced me in the drawing room to her aunt, who also received me most kindly, though you may guess in more venerable fashion, and we had tea \& sat chatting upon all sorts of subjects till $10 . .^{34}$

Actually, Hunt seems to have been somewhat disappointed by the modest size of Mrs. Dashwood's cottage, but was apparently reassured by the fact that she had servants. "The cottage they are in, is small, for them; yet I noticed a footman, \& three female servants in it." 35 There is, however, not the slightest hint of disappointment in his description of the cottage in his poem "Bodryddan":

There, walls were books; and the sweet witch,

Painting, had there the rooms made rich

31 Letter to Marianne Hunt dated August 30, 1835 (MS, Berg Collection, New York Public Library).

32 Letter to Marianne Hunt dated September 3, 1835 (MS, Brewer Collection, The University of Iowa Libraries, MsL|H94hum11|No. 6).

${ }^{33}$ Letter to Marianne Hunt from Anna Maria Dashwood dated August 18, 1835 (MS, Brewer Collection, The University of Iowa Libraries, MsL|D22h).

${ }^{34}$ Letter to Marianne Hunt dated August 26, 1835 (MS, Brewer Collection, The University of Iowa Libraries, MsL|H94hum11|No. 3).

35 Ibid. 
With knights, and dames, and loving eyes

Of heav'n-gone kindred, sweet and wise;

Of bishops, gentle as their lawn,

And sires, whose talk was one May-dawn.

Last, on the roof, a clock's old grace

Looked forth, like some enchanted face

That never slept, but in the night

Dinted the air with thoughtful might

Of sudden tongue which seemed to say,

'The stars are firm, and hold their way.' 36

In a detailed description of Mrs. Dashwood herself, Hunt noted a surprising similarity to Shelley:

Fancy a sort of mixture of Mrs. Gliddon ${ }^{37}$ \& Mrs. Orger, ${ }^{38}$ not so handsome as either in the abstract, but more intelligent \& full of movement. Her person is something like what you guessed it, only of the best of that class, \& not without bosom, though there is not much of it; and what there is comes from a good chest. She shews her teeth when she laughs, like Statia; ${ }^{39}$ and laughs much, \& has bright dark eyes, though not so black and gliding as my Molly's. ${ }^{40}$ She shews her age much in the same way as Statia, \& I guess is just about as old. She wears her hair without a cap, \& long drop earrings, \& her waist has a very broad band. But what would interest you most in her, \& almost startled me to hear, is a high voice, full of breath \& emotion, which reminded me of Shelley. Was it not pleasant to find a resemblance to him in this respect, as in generosity? She seems to speak always at the tip-end of her breath; \& often catches it, something in the way of Francis Edgeworth.41 Her laugh is the going backwards \& forwards of this high breathing voice, short \& quick, like the end of another person's laugh who has been tired with merriment. I guess however she can be very serious \& vehement; \& shall carefully observe her in that respect:-but I am not yet sure. I shall be very sure at all events, in every thing, if need be. ${ }^{42}$

In another letter Hunt extended the similarity of Mrs. Dashwood to Shelley by describing her as a female Shelley. ${ }^{43}$

Mrs. Dashwood apparently kept Hunt so busy during his week's stay, visiting and having tea with her and seeing the sights of the neighborhood

36 "Bodryddan: To the Memory of B. Y. and A. M. D.," H. S. Milford (ed.), The Poetical Works of Leigh Hunt (London: Oxford University Press, 1923), 365.

37 Wife of Arthur Gliddon (1788-1862), owner of a superior snuff and tobacco shop in Covent Garden. The Gliddons had been friends of Hunt since 1819.

38 Mary Ann Ivers Orger (1788-1845), an excellent actress in supporting roles, and a friend of Madame Vestris and of Hunt.

39 Alistatia Gliddon, daughter of Arthur Gliddon.

${ }^{40}$ Marianne Hunt.

41 (d. 1846), brother of novelist Maria Edgeworth.

42 Letter to Marianne Hunt dated August 26, 1835.

${ }^{43}$ Letter to Marianne Hunt dated August 30, 1835. 
such as the cathedral at St. Asaph and the ruin of Rydland Castle, ${ }^{44}$ that, though he had assured Marianne that he would write every day, he apparently wrote her only three times during the week and two of the letters are quite brief and concern mostly necessary communication about his plans for returning to London. Even worse, and perhaps adding to Marianne's possible jealousy of Mrs. Dashwood, is a postscript to his last letter from Rhyll written on the morning of September 2, in which Hunt gave Marianne a bit of a jolt about a book of Shakespeare sonnets he had picked up in Stratford-on-Avon especially for her: ${ }^{45}$

I intended to send your "Shakspeare" by this parcel, \& had not mentioned that I had it till yesterday, when she [Mrs. Dashwood] speaking of the "Confessions" \& saying she had never read the Sonnets, I knew what you yourself could wish me to do with the book, though specially designed for you. I will get you another, forthwith, exactly like it. ${ }^{46}$

But Hunt was determined to spend only a week with Mrs. Dashwood, in spite of his "true regard for her, \& the pleasure of shewing [his] gratitude," because "the thought of home [was] so very, very strong" with him. ${ }^{47}$ Thus, in his letter to Marianne dated September 1, he was, as he had indicated in his letter to her of August 30, planning to take his leave of Mrs. Dashwood at Bodryddan on September 2. He would then proceed with Mr. Ablett, whom he was to meet at Bodryddan, to Llanbedr for the rest of the day and then on to London..$^{48}$

However, duty forced Hunt to stay an extra day in Llanbedr as he explained in his last letter of the trip written to Marianne on September 3 , the day he had planned to begin his return:

I am here with Mr. Landor's friend Mr. Ablett, for a day. I could do no less, since he is a friend of Mrs. Dashwood's also, \& came over to Bodryddan yesterday in his carriage, on purpose to fetch me; \& she, furthermore, wished it. I leave however for Chester tomorrow morning in said carriage, arrive there at noon, \& get the half past one o'clock coach to London, which arrives at your General Post Office the next evening at half past six.

He added, however, that he doubted whether he would "feel it advisable to travel all night." 49

\footnotetext{
44 Ibid.

45 Letter to Marianne Hunt dated from Chester August 24, 1835.

46 MS, Brewer Collection, The University of Iowa Libraries, MsL|H94hum 1 1|No. 5.

${ }^{47}$ Letter to Marianne Hunt dated August 26, 1835.

${ }^{48}$ Letter to Marianne Hunt dated September 1, 1835 (MS, Brewer Collection, The University of Iowa Libraries, MsL|H94hum|No. 4).

${ }^{49}$ Letter to Marianne Hunt dated September 3, 1835.
} 
Ablett seems to have allowed Hunt more time to himself than Mrs. Dashwood did, for in a letter to Marianne he described Llanbedr Hall at some length.

Mr. Ablett's is a very fine house, with very fine grounds, situate in a most beautiful country like a garden, with the gentle Welsh mountains framing the picture all round you. What signifies? I sit in these fine rooms, crammed full of conveniences \& elegancies, \& sigh for my poor housefull of dear children.- I have just come from a walk with him up the mountains to the house of a lady, a friend of his, \& am writing this before dinner. Yesterday in our way from Bodryddan, we stopped \& had a second lunch (for dinner) at Denbigh, a place rising on a mount out of the valley, $\&$ crowned with the ruins of a fine old castle, which we inspected. We then came hither through Ruthin. ...

The whole of this district is intersected with gently undulating fields of grass \& corn \&c. with beautiful trees \& hedgerows, except towards Rhyll, where the seashore commences. ${ }^{50}$

Hunt also found time to describe Llanbedr in a poem which was published two years later in Joseph Ablett's Literary Hours.

Quitting dear friends with homeward care

In the sweet land that held the Druid,

I touched at thee, Llanbedr fair,

Thou lily of the Vale of Clwyd.

Gardens I saw, home's fringes bright,--

A homestead church, and pastoral valleys,

And mountains green of gentle might,

Luring ascent with leafy alleys.

A page from out a poet's book

It was, - - choice Nature's own adorning, -

A landscape worth an angel's look,-

A smile of God on Eden's morning. ${ }^{51}$

It is difficult to know how negotiations over the annuity went for there seems to be no extant document in which anyone said anything directly about it. But things apparently were not running entirely smoothly since Hunt began his letter to Marianne dated September 1, "I have been sadly put out today—oh how sadly—by cross purposes." And he ended his last letter to Marianne: "Cross purposes to the last!!" 52 We can only assume that he was speaking of the proposed annuity. Hunt was notoriously bad at business, as he frequently admitted, and perhaps he optimistically expected the annuity to be set up immediately while he was at Bodryddan. Thus the comment about "cross purposes" may have

so Ibid.

${ }^{51}$ Milford, pp. 366-67.

52 Letter to Marianne Hunt dated September 3, 1835. 
expressed merely his disappointment that it would take longer. However, he shows no disappointment in his poem "Bodryddan," which was published two years later. On the contrary, praise of Mrs. Dashwood remains as fulsome as in his letters.

I met a lady by the sea,

A heart long known, a face desired,

Who led me with sweet breathful glee

To one that sat retired;-

That sat retired in reverend chair,

That younger lady's pride and care,

Fading heav'nward beauteously

In a long-drawn life of love,

With smiles below and thoughts above:

And round her played that fairy she,

Like Impulse by Tranquillity.

And truly might they, in times old

Have deemed her one of fairy mould

Keeping some ancestral queen

Deathless, in a bow'r serene;

For oft she might be noticed walking

Where the seas at night were talking;

Or extracting with deep look

Power from out some learned book;

Or with pencil or with pen

Charming the rapt thoughts of men:

And her eyes! they were so bright,

They seemed to dance with elfin light,

Playmates of pearly smiles, and yet

So often and so sadly wet,

That pity wondered to conceive

How lady so beloved could grieve.

And oft would both those ladies rare,

Like enchantments out of air,

In a sudden shower descend

Of balm on want, or flowers on friend;

No matter how remote the place,

For fairies laugh at time and space.

From their hearts the gifts were given,

As the light leaps out of heaven. ${ }^{53}$

Nor was Hunt's relationship with Mrs. Dashwood anything but friendly in his last extant communication with her three years after his visit. In 1838 he sent a letter to Landor through Mrs. Dashwood because he did not know Landor's address. There is, of course, some question as to whether the annuity was ever set up. Blunden suggests that it was, but

53 Milford, p. 365. 
adds that at some time Mrs. Dashwood seems to have wanted to remarry and asked Hunt to give it up (p. 264). One can only conclude that since Hunt nowhere mentions an annuity, which he surely would have done if there had been one, either it was never actually established or it was terminated very early. It is difficult to guess which because in either case Hunt would have acted in the same generous way toward Mrs. Dashwood, accepting his disappointment with no resentment. 